\title{
Developing higher education's academic literacy in English through tutorials in a Spanish-speaking country
}

\author{
CATALINA SANDOVAL MUÑOZ \\ Universidad de Chile \\ catalsandoval@ug.uchile.cl
}

\begin{abstract}
For the last twenty years, academic literacy in higher education has been a major area of interest for many researchers. In Latin America, the initiatives for the development of students' writing in tertiary education began in the 2000s and range from pedagogical proposals and writing manuals to the creation of writing centers (Arango \& Avila, 2020). This study is set in Armadillo Lab, a recently created writing center at a Chilean university, which offers academic writing tutorials to undergraduate and graduate students in Spanish and English, a language that no other writing center in the country caters to. This quantitative and qualitative study includes 16 tutees over 13 months and the inductive analysis of 33 samples. It seeks to determine the genres students write, analyze tutees' written production, describe the support they received, and show the impact of the tutorials in their writing. Findings revealed a range of academic and professional genres, which were more common at the graduate levels. Issues in genre knowledge and a variety of textual issues were also found and coincide with findings of academic writing done in Spanish. As for the impact of tutorials, these had a strong positive impact on the written skills of students who attended more often. This study is the first focused on the students' production of genres written in English in Chile with a writing center's support, opening up the path for more research in English academic literacy in the country and more work on pedagogical support for Spanishspeakers' English writing.
\end{abstract}

\section{Keywords}

Academic literacy; academic writing; English for Academic Purposes; higher education; writing center. 


\section{Desarrollando la alfabetización académica en inglés a través de tutorías en un país de habla hispana}

\section{Resumen}

Durante los últimos veinte años, la alfabetización académica en la educación superior ha sido una importante área de interés. En Latinoamérica, las primeras iniciativas para desarrollar la escritura en educación superior datan del año 2000 y van desde propuestas pedagógicas hasta la creación de centros de escritura (Arango \& Ávila, 2020). Este estudio se sitúa en Armadillo Lab, un centro de escritura recientemente creado en una universidad chilena que ofrece tutorías de escritura académica a estudiantes de pre y postgrado, en español e inglés. Las tutorías en inglés hacen a este centro único en Chile. Este estudio cuantitativo y cualitativo incluye 16 estudiantes atendidos durante 13 meses y el análisis inductivo de 33 muestras escritas. Los objetivos son determinar qué géneros escriben los estudiantes en inglés, analizar su producción, describir el soporte recibido y mostrar el impacto de las tutorías en su escritura. Los hallazgos revelan una gama de géneros académicos y profesionales, los que fueron más comunes a nivel de postgrado. El análisis mostró además dificultades textuales y de conocimiento de los géneros. Por último, las tutorías tuvieron un impacto positivo en las habilidades de escritura en inglés, en especial de quienes consultaban más frecuentemente. Este estudio es el primero en Chile cuyo foco es la producción de géneros escritos en inglés con el soporte de un centro de escritura, abriendo camino a más investigaciones en alfabetización académica en inglés en países de habla hispana y al desarrollo de material pedagógico específico para escritura en inglés dirigido a hablantes de español.

\section{Palabras clave}

Alfabetización académica; escritura académica; inglés con fines académicos (EAP); educación superior; centro de escritura.

Recibido el 03/08/2020

Aceptado el 17/06/2021 


\section{Introduction}

Academic Literacy refers to the teaching and learning process through which a higher education student acquires (mainly) the written communication forms of their major, discipline and future professional field (Navarro, 2018: 28). From a slightly different perspective, Carlino (2003) defines it as the set of notions and strategies needed to participate in the discourse culture of the disciplines as well as in the activities of text production and analysis that are required to learn at university. One of the main strategies which facilitates students' enculturation process from a literacy perspective is helping students to become competent writers in the genres they are expected to produce (Marinkovich et al., 2016), that is, helping them identify and write these "abstract, socially recognised ways of using language" (Hyland, 2007: 149). In this regard, academic literacy in higher education is also characterized as university's social function of facilitating the access to scientific and/or professional communities (Carlino, 2003).

For the last twenty years, academic literacy in higher education has been a major area of interest for many researchers worldwide (Arango \& Ávila, 2020). In Latin America, the first initiatives for the development of students' writing in tertiary education date back to the early 2000s and range from pedagogical proposals and writing manuals to the creation of writing centers (Arango \& Avila, 2020). At the Latin American level, these writing centers are part of the Latin American Network of Writing Centers and Programs (RLCPE), and in Chile, the location of this study, there are currently four writing centers: Centro de Escritura de la Universidad de Tarapacá (UTA), Centro de Escritura de la Universidad de los Andes, Programa de Lectura y Escritura Académica from Universidad Católica de Chile (PLEA), and the recent Laboratorio de Escritura Armadillo de la Escuela de Ingeniería y Ciencias de la Facultad de Ciencias Físicas y Matemáticas de la Universidad de Chile (Armadillo Lab), founded by the end of 2018 (Sologuren \& Morgado, 2021). All of them develop students' academic literacy skills in Spanish; however, only Armadillo Lab from Universidad de Chile offers tutorials for students who are writing in English.

This study aims to identify the genres tutees consult about, analyze their written production, describe the support given to them, and assess the impact of the tutorials in their English academic writing.

\section{Theoretical Framework}

\subsection{Academic Literacy Studies in Chile}

Within the Chilean context, a recent review of a decade of Chilean studies on academic literacy by Arango \& Ávila (2020) showed that in the 24 articles reviewed, the most frequent academic genre studied was "thesis," with a predominance of undergraduate levels (20 out of 24) and a study focus on textual analysis. Moreover, Marinkovich et al., (2016) studied the types of genres across several disciplines in a 
Chilean university and found that the "essay", "report", and "test" were common instructional genres in all disciplines included in the study. Mathematics, one of the disciplines of the study which is closer to the focus of this research, had "thesis", "test" and "paper" (not the traditional research paper) as the preferred instructional genres. However, a slightly different trend has been observed in science and engineering. Even though studies have also focused on undergraduates, the range of genres is greater (see Soto, 2009; Sologuren, 2019). Of particular relevance to this study is Sabaj's (2009) focus on graduate level's writing of research papers in Spanish. First, he points out that to write these type of genre, students must have general writing strategies, disciplinary knowledge (theoretical and methodological), and knowledge of the genre features (Sabaj, 2009, p. 110). His study concluded that his participants had some micro and macro writing difficulties. At the micro (sentence) level, common difficulties were punctuation, use of Spanish "tilde", wrong lexical selection, and long sentences with no punctuation or clear connection of ideas. On the other hand, difficulties beyond the sentence were the lack of homogeneity in format conventions, lack of information hierarchy or lack of organization of information between sections and subsections, and structural inadequacy (not meeting the requirements of a research paper title, introduction, or other sections). The author stated that the micro level issues were very frequent and that, from a didactic standpoint, these textual difficulties may be easy to solve because they are more basic and they may have occurred due to lack of planning and revision. Finally, he attributed macro level issues to the specific demands of the research paper genre, which requires the mastery of "specific competences" (Sabaj, 2009, p. 124).

It should be noted that although all the aforementioned initiatives have offered invaluable insights into Chilean academic literacy in higher education, three research gaps can be identified: 1) the need to explore which other genres are being written and their type 2) the need to research writing at graduate levels; 3) the need to extend Chilean academic literacy in higher education from research in L1 literacy to L2 (English) academic writing literacy, as all the reviewed studies so far have been done in Spanish as L1.

\subsection{EAP's and Genre Theory's contribution to L2 language learning}

English for academic purposes (EAP) "is concerned with researching and teaching the English needed by those who use the language to perform academic tasks." (Charles, 2013, p. 137). The use of corpora, which includes "a collection of texts compiled according to set criteria" (Charles, 2013, p.138) has made a significant contribution to EAP and related fields, as a corpus can promote language learning by becoming a pedagogical tool (Charles, 2013). For instance, corpora, such as the one used in this study as support, allow students to notice grammar patterns, collocations, and learn the most frequent academic metadiscourse in a variety of written genres and registers. As a result, once the teacher support is removed, they can autonomously search and make informed decisions about their choices. Charles (2013) adds that genre studies, 
specifically the analysis of rhetorical moves by Swales (1990) have also nurtured EAP research.

Genre is defined as "abstract, socially recognised ways of using language." (Hyland, 2007: 149). If these genres are taught, they can first be classified into instructional and expert (or professional) genres: tests, reading responses or essays are considered, for example, can be considered instructional since they mainly evaluate students understanding of disciplinary content; in contrast, expert ones such as papers and research grants focus on the students' communication and construction of new knowledge, which more traditional in academic and professional settings (Marinkovich et al., 2016).

\subsection{Writing Centers in Latin America}

In Latin America, the first writing centers were created in Puerto Rico and México, followed by its South American counterparts Colombia, Argentina, Uruguay, and Chile (Molina-Natera, 2014). Currently, all of them are part of the Latin American Network of Writing Centers and Programs (RLCPE), and in Chile, the location of this study, there are currently four writing centers: Centro de Escritura de la Universidad de Tarapacá (UTA), Centro de Escritura de la Universidad de los Andes, Programa de Lectura y Escritura Académica from Universidad Católica de Chile (PLEA) and the recent Laboratorio de Escritura Armadillo de la Escuela de Ingeniería y Ciencias de la Facultad de Ciencias Físicas y Matemáticas de la Universidad de Chile (Armadillo Lab), founded by the end of 2018 (Sologuren \& Morgado, 2021). All of them develop students' academic literacy skills in Spanish; however, only Armadillo Lab from Universidad de Chile offers tutorials for students who are writing in English.

According to (Molina-Natera, 2014: 19), all of these centers aim to promote reading, writing and any other communicative competence through a non-directive model akin to that of centers in the United States with their L1 speakers, which steer away from text correction towards the development of transferable writing skills. In this vein, writing centers' assistance in L1 and L2 plays a significant role in students' development of academic literacy: it prepares students to join and succeed in their disciplinary cultures by helping them identify, understand, and produce the diverse academic genres that require the teaching, construction and evaluation of that [disciplinary] knowledge (Nesi \& Gardner, 2012; Navarro \& Aparicio, 2018).

\section{Research Questions and Hypotheses}

The four research questions that will be addressed in this study are listed below; they are presented with their corresponding hypotheses, which will be later confirmed or refuted in the Discussion and Conclusion section.

(1) Which genres do all tutees (undergraduate and graduate) write in English at a Chilean university's writing center? 
Hypothesis: Tutees write a variety of genres in English, while Thesis and Dissertations are the most common genres written by the tutees.

(2) What are the characteristics of the tutees' written production in English?

Hypothesis: Tutees' writing is intelligible, but it has textual issues as a result of negative transfer from Spanish.

(3) What is the support given to tutees?

Hypothesis: The support is varied and depends on the tutee's needs.

(4) How does this support impact the tutees' written production in English?

Hypothesis: The support given impacts tutees' written production positively, as they improve their English writing.

\section{The context of this study}

\subsection{The Armadillo Lab and its tutees}

The Armadillo Lab was founded in 2018 (Sologuren \& Morgado, 2021), and its mission is to "enable students to achieve excellence by developing and strengthening advanced communication skills according to international standards" (Facultad de Ciencias Físicas y Matemáticas, 2019: 1). Besides its main goal, its most distinctive feature is becoming a support network in Spanish and English, pioneering academic and professional literacy education in this language in the country. Armadillo Lab carries out its mission through one-to-one writing tutorials and biannual writing workshops in both languages, among other research-oriented tasks.

Tutees who need help with their writing in English are undergraduate and graduate. It was not possible to obtain the specific data to characterize their English proficiency with certainty. However, all undergraduate students must take compulsory general English courses focused on in aural and oral skills; they are also expected to have some understanding of English, as of 2019 there were 12 lectures in English on campus. Tutees included in this study consulted because their professors encouraged them to write academically (theses and dissertations) and professionally (research papers) in the case of graduate students. Therefore, it may be safe to say they had some working knowledge of English to carry out these tasks.

This study covers the work with 16 tutees who made an appointment with the Armadillo Lab's ESP specialist in a 13-month period ranging from March 2019 to May 2020 (January and February 2020 were excluded due to summer break). In total, there were 64 free of charge, one-hour tutoring sessions for those 16 undergraduate and graduate tutees from several science and engineering majors (Industrial Engineering, Electrical Engineering, Geology, and Computer Science, among others). The students could attend as often as they needed to and had to fill in a form to set up an appointment. 
In all, they sought consultations ranging from 1 to 13 times during that period, so some tutees consulted only once (5 students) while others consulted twice (2), 3 (3), and 4 (2) times. On the other hand, $12,5 \%$ (2) consulted 7 times while 2 students consulted 13 times.

The sessions were all conducted in Spanish for easier communication and more relaxed atmosphere, except when two students requested English for more practice. In the first session, students were asked to introduce themselves and briefly explain what had brought them to Armadillo. After that, the specialist clarified the purpose of the lab: to help students be better communicators in academic and professional genres in English, and neither a language class nor an editing service is provided. The tutor emphasized the Lab's pedagogical mission by telling students they needed to make an appointment in advance (not last minute before a deadline) and most importantly, be willing to commit to a "work plan" for as many sessions as they could if they wanted to make progress.

Then the specialist asked students to show her their documents written in English, which were used as a need's assessment tool. If the student reported being able to attend just once due to time constraints, the specialist read the sections seen as most relevant by the student and focused on global and then local issues, as suggested by Harris and Silva (1993). All these were explained and solved them with the student (e.g. cohesion in a paragraph) but minor issues were pointed out and explained only if they were frequent. Finally, students were given general recommendations for future writings. Conversely, if students reported having the time and interest, the specialist elaborated a work plan based on the students' reported needs and those found in the sample and then socialize it with the student in the first or second session.

From then on, tutorials were held once a week for as long as students requested them; students worked mostly with worksheets designed by the specialist that targeted their difficulty areas or with their own drafts depending on the writing stage. They were usually given homework or asked to bring a new draft in case they were working on a thesis/dissertation chapter or a research paper section so that they were able to apply what they had learned in the sessions. In all cases, if relevant, the specialist shared free online resources to enhance academic vocabulary knowledge autonomously.

Throughout the sessions, the tutor/specialist transitioned from a more directive to a non-directive, facilitator, and peer-perception role. In its more directive role, which was minimal, the specialist provided the student with the theoretical foundation to understand the nature of the issue, identify it, and repair it to later apply the revision or strategy successfully into their own writing. Once students started mastering the most serious issues affecting intelligibility and showed drafts with their improvements in those areas, the specialist became a peer-perception figure since it read students work and commented on issues pertaining mostly to greater clarity and conciseness. When issues previously discussed appeared, the specialist stopped and gave indirect feedback by only asking students to verify if that was correct or not and why.

On the other hand, as evidenced by these session descriptions, the students' role was paramount. For greater improvement, they were expected to attend regularly and as much as possible to improve in the areas defined in the work plan. In addition, they 
were expected to do homework or draft revisions to apply contents practiced in each session. This means students had a key role in their own improvement, as over time, they were expected to notice and repair errors they had previously been working on. Often, they also took on their subject-expert role when explaining technical excerpts so that the specialist was able both to understand the idea they intended to express and provide them suitable suggestions for how to express their message in the most accurate and clear manner while keeping the technical content intact.

\section{Methodology}

This study is based on an exploratory approach that combines quantitative and qualitative methods. To answer research question 3 , the researcher collected all samples voluntarily brought by tutees to the sessions. Due to its exploratory nature, all samples (33) the 16 tutees (5 undergraduate and 11 graduate students) brought to the session were considered for the analysis, regardless of how many sessions students attended. However, if they attended only once, these samples were not used to attest for writing improvement. In some cases, completed writing-related homework was assigned by the researcher and has also been included (identified as "HW"). The samples were in English and varied in length and stage of development: some were an entire section of a thesis or article, and others were a few paragraphs. Besides the student samples, to answer research questions 1,2,4 and 5 a "Student Text Chart" was created to record the following: student name and number (1-16), major and level, session number, genre the sample belonged to (which was self-reported by tutee when making an appointment), academic or professional genre, support given by the specialist, and text version number. It should be noted that the terms "academic" and "professional" genre are derived from Armadillo Lab's own name: academic genres correspond to those restricted to university settings and course requirements, while professional ones extend to the workplace and further career opportunities of students outside university requirements. Finally, to facilitate sample identification, the code "WS" and a number 1-16 will be used to match each student.

All the data analysis was done manually by the researcher by the end of the tutoring period. First, the researcher used the "Student Text Chart" and then identified, classified, and counted the genres consulted per student level. Then the researcher read the students' samples several times and conducted a manual analysis of students' writing with no predetermined categories, which were finally grouped into two "global" categories: genre knowledge and textual issues. To attest for writing improvement, the researcher manually determined whether the tutee's latest version exhibited the issues present in the first session's text or not. Below are succinct definitions of the emergent categories, which will be illustrated in the results section.

\subsection{Genre knowledge}

Genre knowledge refers to the extent of familiarity with the genre consulted in terms of structure or content. 


\subsection{Textual issues}

These issues cover five "local" categories: mechanics, grammatical accuracy, cohesion, vocabulary, and style, which were not predetermined. Each of these is defined below.

- Mechanics: it includes sentence structure and punctuation errors.

- Grammatical accuracy: presence of grammar mistakes of various types.

- Cohesion: it is defined as "the connection of sentences to one another, to the "flow" of a text, to the ways in which a paragraph of separate sentences becomes a unified whole" (Kolln, 2003: 26). Thus, subcategories include use of cohesive devices and sentence variety.

- Vocabulary: it refers to the lexical choices made by students in terms of adequacy to academic discourse and lexical variety. Adequacy means the use of standard lexical choices for a specific genre instead of unidiomatic expressions and the appropriate register (formal). On the other hand, variety of lexical choices is related to the repetition of a lexical item instead of using synonyms.

- Style: The degree of adherence to academic writing style rules of conciseness, use of formal words and contractions (University of Reading, n.d.).

\section{Results}

\subsection{Genres written in English by all tutees attending the center}

The first question of the study was the following: Which genres do all tutees (undergraduate and graduate) write in English at a Chilean university's writing center? The analysis conducted showed that all students wrote both academic and professional written genres in English. Academic genres were the most common, concentrating 11 of the 16 tutees. Of those 11,9 were at the graduate level, who also represent $68.7 \%$ of all tutees in the study. Undergraduates consulted for a thesis and a report with a research paper structure, while graduates consulted about a doctorate dissertation, a research paper at the graduate level for publication in specialized international peerreviewed journals, and master's thesis. Figure 1 shows genres grouped by type (academic or professional), student's education level (undergraduate or graduate) and how many students consulted about this genre (in parenthesis). For professional genres, undergraduates in their last year consulted about a motivation letter for master's scholarship ( 1 student), a resume ( 1 student), and a cover letter ( 1 student). Graduates, on the other hand, consulted about research papers that were about to be submitted for peer-review and publication (2 students). 


\begin{tabular}{ccc} 
& UNDERGRADUATE LEVEL & GRADUATE LEVEL \\
\hline $\begin{array}{c}\text { ACADEMIC WRITTEN } \\
\text { GENRES }\end{array}$ & $\begin{array}{c}\text { Undergraduate thesis (1) } \\
\text { Written report with } \\
\text { traditional IMRD structure } \\
\text { PROFESSIONAL }\end{array}$ & $\begin{array}{c}\text { Master's thesis: (4) } \\
\text { PhD Dissertation (2) } \\
\text { Research proposal for } \\
\text { internship abroad (1) } \\
\text { PhD Qualifying exam (2) }\end{array}$ \\
\hline WRITTEN GENRES & $\begin{array}{c}\text { Motivation letter for master's } \\
\text { scholarship (1) } \\
\text { Resume (1) } \\
\text { Cover letter (1) }\end{array}$ & IMRD Research papers (2) \\
& &
\end{tabular}

Figure 1. Written genres consulted per type and student level

\subsection{Characteristics of tutees' written production in English}

The second question of this study referred to the characteristics of the tutees' written production in English. Results in this section will be presented based on the categories defined in 5.1 and 5.2 .

\subsubsection{Genre knowledge}

Issues in this category were characteristic, but not limited to, students working on IMRD thesis, dissertation, or class IMRD-type report. Both undergraduate and graduate tutees exhibited the following problems: some, who reported having little or no writing experience showed incomplete thesis or research paper sections, misplaced or irrelevant rhetorical moves, and use of unidiomatic academic phrases. Some examples of this category are shown in Figure 2:

Move 1 (topic generalization): "Reading Comprehension for question-answering (RCQA) is a wellknown task in the machine learning (ML) community."

Move 2 (continuing a tradition): "Consequently, it is important to be aware of QA challenges and cutting-edge models."

Move 3 (outlining purpose): "In this research survey we are going to show...datasets"

Move 1 (topic generalization): "Multiple datasets...."

Move 3 (announcing present research): "We introduce this three-layer architecture..."

Move 1 (setting the context): "In addition to baseline model architectures, RCQA challenge datasets also provide a reasoning empirical analysis."

Move 3 (announcing present research): "We discuss that the empirical evaluation is of great aid..." Study's contribution: "The presented datasets and its models are of great value for many applications..." "This research survey main contribution is to..."

Move 3 (indicating article structure): "This paper is structured as follows:"

Figure 2. Student's introduction sample (WS10)

As Figure 2 shows, the student is unable to follow a logical sequence from move 1 to 3 , and constant changes result in an introduction lacking cohesion. Moreover, he adds 
irrelevant moves (contributions of the study), which does not belong to the introduction moves defined by Swales (2014) (see Figure 3).

Move 1: Establishing a Territory: setting the context or needed background through claiming centrality and/or making generalizations and/or reviewing past research.

Move 2: Establishing a Niche: counterclaiming, indicating a gap, raising a question, continuing a tradition.

Move 3: Occupying a Niche: outlining purposes or announcing present research; announcing principal findings; indicating the structure of the research article.

Figure 3. Introduction moves by Swales (2014: 12-14)

Other tutees, such as the one showed in the sample below, fail to use idiomatic academic vocabulary:

"With respect to hypothesis (3) no evidence helps to argue it, as we do not clearly observe some cold aquifer in the Fucha spring proximity. However, it is not disposable due to the river proximity and the cold creek close to the springs." (WS11: paper discussion section).

Unidiomatic choices such as "helps to argue it" was chosen instead of a more idiomatic "was found to support it." The same occurs with the collocation "disposable" to characterize "hypothesis" when the more idiomatic collocations would be "rejected, discarded."

\subsubsection{Textual issues}

Issues related to mechanics were present in students across levels. Several students had some long, stringy sentences as well as sentence fragments. In the case of stringy sentences, these were considered problematic due to their excessive subordination and impact of intelligibility, as shown in the excerpt (WS2) below. Fragments were not as common, but they affected intelligibility as well:

(WS2): "In the case of land vehicles, an appropriate operation mechanism is highly relevant to face the above, because operation costs depend on that mechanism, while the environmental impact of the vehicle in this life stage is the greatest [5][6], being essential to count with an efficient handling of resources and optimize decision making."

On the other hand, every student presented at least a few punctuation issues, specifically the absence or overuse of commas, with varying impact on intelligibility. Two excerpts illustrate this issue, WS1 and WS5 in Figure 4 (punctuation issues are indicated in parenthesis and italics in the place they occur). 
WS1: "To model the telescope Mueller matrices are used. (comma needed after introductory phrase). They model the changes of the Stokes vector of the light throughout an optical device, describing the changes of: I, Q, U and V (colon misuse)."

WS5: "Resilience is applied to many fields of engineering, (comma splice) we also analyzed other metrics and the application area distribution that was obtained is shown in Fig. 2."

\section{Figure 4. Examples of students' punctuation issues}

In the area of grammatical accuracy, the categories found were agreement, verb tense consistency, and use of prepositions/definite article/verb "allow." The first issue observed was subject-verb agreement and the agreement between demonstrative pronoun number and number/verb form (see (a) WS2 below with errors in italics); the other was verb tense/aspect errors in the methodology and results sections. In (b) the student reports results with a verb phrase in present continuous instead of past simple (ranged), which is later attempted to be used despite the misspelling "*where recorder" instead of "were recorded." Similarly, in the second excerpt, the same student reports procedures incorrectly in present simple instead of past simple and then includes a final incorrect past reference that needed past perfect (had been mapped); one final issue covers a mixture of minor elements such as use of the definite article, prepositions, and the verb allow (see example c), which was translated directly from Spanish and resulted in ungrammatical excerpts.

(a) WS2: "From an economical point of view, the cost of investing on transportation systems and its future operation can be very high." "This mean that the absorption is stronger...and hence, the amount of irradiance [is] scattered."

(b) WS11: "Resistivity of the tomographies results are ranging between 1 and $6300 \mathrm{ohm}-\mathrm{m}$. Low resistivities between 1 and $63 \mathrm{Ohm}-\mathrm{m}$ *where recorder only close to thermal spring." "To obtain representative values for pristine rocks, we install an ERT in a high-energy sedimentary environment...where a small sedimentary thickness is expected, and where intrusive rocks were already mapped."

(c) WS1: "The study of the variation of blazars light, in particular its polarization, allows to understand the physical changes on them."

Figure 5. Examples of students' grammatical accuracy issues

Another problematic area was cohesion, defined as "the connection of sentences to one another, to the "flow" of a text, to the ways in which a paragraph of separate sentences becomes a unified whole" (Kolln, 2003: 26). The issues observed in this area were limited cohesive devices (overuse of conjunctive adverbs as a cohesion strategy), misused connectors (meaning, syntactically, punctuation), a limited range of conjunctive adverbs, and lack of sentence variety. 
Indeed, conjunctive adverbs were the most common cohesive device strategy along with anaphoric reference; however and moreover, were the most frequently used conjunctive adverb, with a few cases where there was a clear overuse of them. In some cases, connectors such as although were misused as conjunctive adverbs at the beginning of sentences. What seemed surprising was that despite the common use of connectors, these were mostly limited to coordinating conjunctions and conjunctive adverbs with scarce use of subordinating conjunctions, as illustrated by WS8 and the 3 conjunctive adverbs in italics (Figure 6):

Figure 6. Example of a students' cohesion issues

WS8: "Traditionally, P-DPs are dealt with a structured way because automation of such processes provides efficiency to organizations, however, it limits engineers to predefined activities and conditional flows. Therefore, communities from specific areas such as BPM, ACM, CSCW, and KM have intended to provide support to P-DPs design and implementation issues. Nevertheless, it has resulted into complex solutions or with several limitations to be adopted."

Regarding sentence variety, several students exhibited a choppy style, that is, they tended to use simple sentences almost exclusively. If complex sentences were used, these were scarce and limited to sentences containing only adjective clauses, so there was scarce use of other complex sentence possibilities such as noun clauses or adverb clauses.

Vocabulary was another area showing some room for improvement. This category refers to the lexical choices made by students in terms of adequacy and variety. Adequacy means the use of standard lexical choices for a specific genre instead of unidiomatic expressions and the appropriate register. In this case, the adherence of an academic, formal register. Variety of lexical choices was also considered, specifically reporting verbs. The categories found were the following: use of unidiomatic expressions, lack of knowledge of words' register, and a limited range of reporting verbs.

The more unfamiliar the genre section or chapter was, the greater use unidiomatic expressions there was (see (a) WS5 IN Figure 7). For register, students sometimes used generic, non-academic words (e.g.: get, big, a lot) instead of a more academic choice (see (b) below). Finally, when it came to reporting ideas in the literature review or discussion sessions, students generally used a limited number of reporting verbs (e.g.: state, say, discuss) or misused others (e.g. mention instead of pointed out, argued.).

\section{Figure 7. Examples of students' vocabulary issues}

(a) WS5: Accordingly, the framework we propose aims at filling this lack in planning a multienergy system." (Instead of "filling the gap")

(b) WS14: "X-Ray Diffraction is a technique based on bombarding crystalline structure with $\mathrm{X}$ rays to get a diffraction pattern. The shape of the pattern strongly depends on the microstructure, so this technique has become a useful tool to get information from it." 
The last issue observed was in writing style, in that students did not follow the academic writing style rules of conciseness and use of formal words and no contractions (University of Reading, n.d.). Therefore, the categories were wordiness, informal words and contractions, as illustrated in italicized phrases in (a) and (b) in Figure 8:

Figure 8. Examples of students' style issues

(a) WS16: Through this experiment, Chevalier attempted to understand display's impact among different types of products. Thus, besides the cut price levels, his approach considered variables that were not, by incorporating in previous studies, variables such as product lifecycle, category competitive structure and competitive position of a brand.

(b) WS15: "My goal is to continue getting deeper in my knowledge and practice in the area of applied physics and radioelectronics, that's why I ask you to consider me for this master.

\subsection{Support given to tutees}

This section presents the results for the third research question: What is the support given to tutees? This question will be answered based on each issue defined in section 5: Genre knowledge and Textual Issues. To address genre familiarity issues, the specialist designed and provided the students with a worksheet on Introductions and Methodology created by herself. For the literature review, several sources were used: a concise, clear video about how to do this section from a well-known Australian university, digital worksheets and information on how to organize the section, and an infographic titled "How to read research papers?" from an American university website. Vocabulary support for all these sections was provided with an external resource: The Academic Phrasebank website of a reputable English university.

For all textual-related issues, the following series of consecutive topic-specific worksheets were created 1) Sentence types and sentence combination, 2) Complex sentences with adverb clauses, 3) Fragments, 4) Punctuation, 5) Repairing long sentences. The idea was that students began with the first one and moved on progressively onto the others, with increased level of complexity. All of them were structured around samples and asked for identification, controlled production, and final application of content by identifying and improving their writing in future drafts or other academic writing tasks in English.

Another source of support was the in-class oral feedback highlighting the error and explaining it a few times in one session, which was sufficient for students to increase future awareness and self-correction. Furthermore, to address definite article questions, students were given external material with exhaustive explanations for maximum clarification; for preposition use as well as register awareness, they were shown useful external resources such as the online Corpus of Contemporary American English (COCA) and reliable monolingual online dictionaries. They were given a brief "tour" of most useful features in addition to a quick practical tutorial on how to do collocation searches and how to determine a word's register. Finally, in case of the 
misuse of the verb "allow," the specialist created a worksheet summarizing its different syntactic possibilities and providing some controlled and free practice.

For cohesion devices awareness and practice, especially of subordinating conjunctions, students were given a connectors chart which was adapted from an academic writing book to incorporate more connectors as well the syntactic and punctuation rules applicable to each. A cohesion - sentence variety worksheet was also created by the specialist to support this difficulty area, which improved when taught after the mechanics-related worksheets.

\subsection{Support's impact on tutees' writing in English}

This last result section aims to answer the fourth research question: How does this support impact the tutees' written production in English? Based on a manual examination of students' latest versions, the impact of ESP tutoring sessions was positive for their writing in English. It was observed that the more often students attended, the more progress they made. Student 11 and 16 attended quite often and exhibited more improvement. Because student 16's issues were already included in the textual issues section, only student 11's improvement will be illustrated here. Student 11's first version (a), written in October, 2019 had many grammatical inaccuracies, wrong punctuation and vocabulary (mistakes are shown in italics and corrections in parenthesis), which were absent in the final version by March, 2020 after 11 sessions (b):

(a) "We can apply the Archie's law (equation 3) from the mean values define (defined) in Table 1, (unnecessary comma) to estimate the electrical resistivity of the porous medium fill (filled) with each different water (resume (summarized) in Table 2). For cold aquifer and surface (absent comma) waters bulk electrical resistivities may ("should" to express what needs to occur) ranges (range) from 250 to 1900 Ohm-m. Conversely, a porous media filling (filled) with thermal water have (has) electrical resistivity ranging between $\sim 40$ and $160 \mathrm{Ohm}-\mathrm{m}$, which means a completely different range."

(b) “Mean values defined in Table 1 coupled with Archie's law (equation 4) provide an estimation of the electrical resistivity of the porous medium filled with different types of water (seen in Table 2). For cold aquifer and surface water, bulk electrical resistivities should range from $\sim 250$ to 1900 Ohm-m. Conversely, a porous media filled with thermal water should have an electrical resistivity ranging between $\sim 40$ and 160 ohm-m, which means a completely different range."

(c) As version in (b) shows, the student has changed some of the wording and eliminated the initial errors. 
To further illustrate his progress, the same tutee was able to demonstrate his newly acquired skills after 3 sessions. The homework consisted of improving a paragraph (see "Original Paragraph" below) by combining sentences as well as modifying conjunctive adverbs and subordinators for a more cohesive and syntactically varied paragraph.

Original paragraph (taken from Hogue \& Oshima, 2006):

A robot is a mechanical device that can perform boring, dangerous, and difficult tasks. First of all, robots can perform repetitive tasks without becoming tired or bored. They are used in automobile factories to weld and paint. Robots can also function in hostile environments. They are useful for exploring the ocean bottom as well as deep outer space. Finally, robots can perform tasks requiring pinpoint accuracy. In the operating room, robotic equipment can assist the surgeon. For instance, a robot can kill a brain tumor. It can operate on a fetus with great precision.

This was his version (improvements are in bold and explained where they appear, in italics):

A robot is a mechanical device that can perform boring, dangerous and difficult tasks. Thus, (change of connector to express a better logical connection between this sentence and the last one) robots can perform repetitive tasks without becoming tired or bored; for example, (addition of connector) they are used in automobile factories to weld and paint. Even in hostile environments they can develop different functions, so they are useful for exploring the ocean bottom as well as deep outer space (two simple sentences into one compound sentence joined with coordinating conjunction "so"). Finally, robots can perform tasks requiring pinpoint accuracy, and (despite the mistake in punctuation, the student has clearly attempted a compound sentence arising from 2 initial simple sentences) has been used in the operating rooms as surgeon assistant. For instance, a robot can kill a brain tumor or operate on a fetus with great precision (two simple sentences have been blended into one). (WS 11 - HW)

\section{Discussion and Conclusion}

This study, developed at a Chilean writing center, aimed to identify the genres tutees consult about, analyze their written production, describe the support given to them, and assess the impact of tutorials in their academic writing.

The first research question was which genres students consulted about at both the undergraduate and graduate levels. It was hypothesized that thesis and dissertations would be the most common genres across levels. This was confirmed by the analysis, as those two genres accounted for 7 out of the 16 genres consulted. Although in this study the genres were brought by each tutee to the sessions, and not chosen arbitrarily by the researcher, it is still somewhat comparable to Arango \& Ávila (2020) and Marinkovich et al.'s (2016) results of the thesis genre as the most frequent in several disciplines. The results are somewhat comparable in the sense that they show the prevalence of the 
thesis genre in Chilean university settings as the preferred one to display students' academic literacy instead of others.

Similarly, this study confirms the variety of genres, supported by Soto (2009) and Sologuren's (2019) observation that in science and engineering the range of genres is greater than in other disciplinary areas, as there were several professional genres of which there is no mention of in Arango \& Ávila (2020) and Marinkovich et al.'s (2016). This may be explained by the vastness of science and engineering areas that permeate many industries or by the fact that the focus of those two studies was undergraduate levels where professional writing is still not required.

Finally, unlike Arango \& Ávila (2020)'s observation of the absence of Chilean academic literacy developed at the graduate level, the present study had an unexpected result: it showed that there were more appointments concerning graduate level genres (11) than undergraduate ones (5). This finding seems to suggest that genres at the graduate level may be a fruitful, yet underexploited, area for further research and students' pedagogical support.

In relation to the second research question, tutees' English writing was expected to be intelligible, but to exhibit textual issues as a result of negative transfer from Spanish. Although their writing was quite intelligible, results showed that besides textual issues, tutees lacked enough genre knowledge. Similar findings were reported by Sabaj's (2009), whose study participants were also Chilean graduate students, but who developed research papers in Spanish. Punctuation, wrong lexical selections, and long sentences with no punctuation or clear connection of ideas were common, as well as structural inadequacies. These findings seem to suggest that perhaps the issues found in the present study arise from negative L1 transfer. Sabaj (2009) also hints at lack of planning and revision, which may partially explain the findings of the present study.

Nevertheless, from a more anecdotal point of view, the issues found in this study's samples in English may also be the result of simply insufficient or lack of knowledge of English grammar, vocabulary, and style that is preferred in English academic writing. Indeed, these were the most frequent comments made by every tutee on their first session, which also shows their lack of confidence in their English writing skills.

In response to the third and fourth research questions, the support given was varied and differed from tutee to tutee (which was expected), and there was a positive impact on tutees' written production in English. The examples of improvement in textual issues only after some sessions illustrate that as Sabaj (2009) argues, micro level textual issues may be easy to solve through pedagogical means, which shows that the study has interesting pedagogical implications.

Some of the limitations of this study were the following: attesting for improvement was limited since several students attended only one session, the sample size was small, and the researchers' background in linguistics may have caused a textual bias in the results. Notwithstanding these limitations, this study contributes by being the first to focus on the students' production of academic and professional genres written in English in Chile, which opens up the path for more research of what other genres in other fields students need to write in English. Further, it may motivate more work on 
pedagogical support that prepares students to become competent bilingual academic writers in a globalized world.

\section{Referencias bibliográficas}

ARANGO, L. y ÁVILA, N. (2020). Alfabetización académica chilena: revisión de investigaciones de una década. Literatura y Lingüística, vol. 40(41), 455-482.

CARLINO, P. (2003). Alfabetización académica: un cambio necesario, algunas alternativas posibles. Educere, vol. 6(20), 409-420.

CHARLES, M. (2013). English for Academic Purposes. En PALTRIDGE, B. y STARFIELD, S. (Eds.). The Handbook of English for Specific Purposes. John Wiley \& Sons, Inc., 137-153.

FACULTAD DE CIENCIAS FÍSICAS y MATEMÁTICAS (2019). Documento de implementación: "Mundo académico y profesional en conexión: Estrategias discursivas para el abordaje de diferentes géneros orales y escritos en el área de ingeniería y ciencias.” Facultad de Ciencias Físicas y Matemáticas de la Universidad de Chile.

HARRIS, M. y SILVA, T. (1993). Tutoring ESL Students: Issues and Options. College Composition and Communication, vol. 44(4), 525-537.

HOGUE, A. y OSHIMA, A. (2006). Writing Academic English. Pearson English Language Teaching.

HYLAND, K. (2007). Genre Pedagogy: Language, Literacy and L2 Writing Instruction. Journal of Second Language Writing, vol. 16(3), 148-164.

KOLLN, M. (2003). Rhetorical Grammar: Grammatical Choices, Rhetorical Effects (4th $^{\text {th }}$ ed.). Pearson.

MARINKOVICH, J.; VELÁZQUEZ M.; CÓRDOVA, A. y CID, C. (2016). Academic Literacy and Genres in University Learning Communities. Ilha Desterro, vol. 69(3), 95-113.

MOLINA-NATERA, V. (2014). Centros de escritura: una mirada retrospectiva para entender el presente $\mathrm{y}$ futuro de estos programas en el contexto latinoamericano. Legenda, vol. 18(18), 9-33.

NAVARRO, F. y APARICIO, G. (2018). (Eds.). Manual de lectura, escritura y oralidad académicas para ingresantes a la universidad. Bernal: Universidad Nacional de Quilmes.

NAVARRO, F. (2018). Más allá de la alfabetización académica: las funciones de la escritura en educación superior. En Alves M. A. y Iensen Bortoluzzi V. (Eds.), Formação de Professores: Ensino, linguagens e tecnologías. Porto Alegre, RS: Editora Fi.: 13-49.

NESI, H. y GARDNER, S. (2012). Genres across the Disciplines: Student Writing in Higher Education. Cambridge: Cambridge University Press.

SABAJ, O. (2009). Descubriendo algunos problemas en la redacción de Artículos de Investigación Científica (AIC) de alumnos de postgrado. Revista Signos, vol. 42, 107-127. 
SOLOGUREN, E. (2019). Approche de l'écrit académique dans un milieu d'apprentissage de l'Ingénierie Civile en Informatique. Policromias-Revista de Estudos do Discurso, Imagem e Som, vol. 4, 52-65.

SOLOGUREN, E. y MORGADO, P. (2021). Departamentalización en el aprendizaje del discurso académico: una experiencia chilena para la alfabetización académica y profesional en ingeniería y ciencias. Revista Linguagens \& Letramentos, vol. 6(1), 31-55.

SOTO, G. (2009). Intertextualidad explícita en textos académicos de estudiantes universitarios. Un estudio exploratorio. Literatura y Lingüística, vol. 20,141157.

SWALES, J. M. (1990). Genre analysis: English in academic and research settings. Cambridge, England: Cambridge University Press.

SWALES, J. (2014). “Create a Research Space”” (CARS) Model of Research Introduction. En WARDLE, E. y DOWNS, E. (Eds.). Writing about Writing: A College Reader. Bedford/St. Martin's: 12-15.

UNIVERSITY OF READING (s.f.). Academic writing. https://libguides.reading.ac.uk/writing/style. Fecha de consulta: 13 de diciembre de 2021. 